\title{
Sandy Soil Reclamation Using Biochar and Clay-Rich Soil
}

\author{
Diep Pham Thi ${ }^{*}$, Nga Nguyen Thi Hang ${ }^{2}$, On Tran Viet ${ }^{2}$, Loc Nguyen Van ${ }^{3}$, \\ Anh Nguyen Viet' ${ }^{2}$, Phuong Dinh Thi Lan², Nguyen Vu Van ${ }^{3}$ \\ 1 Institute for Water Resources Economics and Management, 131 Chua Boc, Dong Da, Ha Noi, Viet Nam \\ 2 Thuyloi University, Vietnam, 175 Tay Son, Dong Da, Ha Noi, Viet Nam \\ ${ }^{3}$ Vietnam National University of Agriculture, Trau Quy, Gia Lam, Viet Nam \\ * Corresponding author's e-mail: diepait@gmail.com
}

\begin{abstract}
The investigations on the effects of biochar application in improving the physio-chemical properties of soil have been carried out in many studies; however, there are very few studies on the combined use of both biochar and clay-rich soil for poor nutrient soil reclamation. Therefore, this study demonstrates improved water retention and nutrient retention of sandy soil by using biochar and biochar combined with clay-rich soil. The experiments were conducted on a small scale (greenhouse) with nine different application rates of biochar and clay-rich soil were mixed and then cultivated peanut, along with the drip irrigation technique using field moisture limit (about $70-80 \%$ ) was applied under the condition of ensuring a sufficient supply of NPK for plant's growth. The results showed that at the rates from $10.0-15.0 \%(\mathrm{w} / \mathrm{w})$ clay-rich soil mixed with from $0.5-1.5 \%(\mathrm{w} / \mathrm{w})$ of biochar applied to the tested sandy soil resulted in the positive effects on soil water holding, bulk density, permeability, $\mathrm{pH}, \mathrm{CEC}$, $\mathrm{OM}$, total $\mathrm{N}$, total $\mathrm{P}$ and peanut yield. The physical and chemical characteristics of the tested sandy soil have been improved by time and the application rate of $10.0 \%$ clay-rich soil and $0.5 \%$ biochar had the highest efficiency of pod fresh weight and pod dry weight during three studied seasons.
\end{abstract}

Keywords: sandy soil; biochar; clay-rich soil; physical and chemical properties

\section{INTRODUCTION}

Numerous studies around the world have shown that natural materials and agricultural byproducts such as biochar, rotten rice straw, organics, etc. can be used to improve soil nutrition, limit environmental pollution and help to reduce the greenhouse gas emissions [Zeid et al. 2015, Głąb et al. 2016]. Using organic materials significantly improves the retention of water and organic matter in sandy soil, especially increasing the height of trees, the weight and nutrients of radish, because organic fertilization increases the available amount of $\mathrm{Fe}, \mathrm{Mn}$ and $\mathrm{Zn}$ in the soil compared to other sand reclamation methods [Zeid et al. 2015]. The physical properties of sandy soil were significantly improved when using both biochar and compost compared to the control. The basic physical parameters of the soil such as the bulk density and total porosity depend mainly on the rate of biochar added and the most effective application rate of biochar was found at $4 \%(\mathrm{w} / \mathrm{w})$ [Głąb et al. 2016]. Another research by Molnár et al. [2016] found that applying rice husk biochar and paper mud biochar at rates of $1.0 \%(\mathrm{w} / \mathrm{w})$ and $0.5 \%(\mathrm{w} / \mathrm{w})$ mixed with compost could provide a more inhabitable habitat for plants and animals living on land, compared to the no treatment option [Molnár et al. 2016].

Jeffery et al. [2011] found the benefits of biochar addition to crop yield with the application rate of $10 \%(\mathrm{w} / \mathrm{w})$, the results were statistically significant. The most positive results are related to biochar application to acidic soils (14\% yield increase), neutral $\mathrm{pH}$ soils (13\%), coarse soils $(10 \%)$ and medium textured soils $(13 \%)$ [ Jeffery et al. 2011]. The treatment of sandy soil with biochar maintained more water in a gravity-draining 
equilibrium (up to $15 \%$ ), giving a greater water holding capacity (WHC) at -1 and -5 bar (higher $13 \%$ and $10 \%$ respectively), greater specific surface area (up to $18 \%$ ), higher CEC (up to $20 \%$ ), and $\mathrm{pH}$ (up to 1 unit) compared to the control [Laird et al. 2010]. Ismail and Ozawa [2007] found that sandy soil was mixed with clay with the ratio of $16.5 \%$ of clay and $83.5 \%$ of sandy soil (5.6 kg of clay mixed with $28.4 \mathrm{~kg}$ of sandy soil) helped to increase the area of cucumber leaves as well as stem length, stem diameter and the number of leaves of maize. The yield was increased by 2.5 times compared to the control. The roots grew deeper in the clay treated layers. The treatment retained higher water contents than the untreated control. The water use efficiency increased through clay application, about 45-64\% water was saved compared to the control [Ismail and Ozawa 2007]. The clay soil addition had a positive effect on the available $\mathrm{N}$ and $\mathrm{pH}$ in the tested soil [Pal and Marschner 2016]. The research by Reuter [1994] showed that the application of clay can improve sandy soil with water regime and percolation processes which reduce the plant nutrient losses and ground water contamination.

Coastal sandy soil plays a huge role in the agricultural production of coastal areas, especially in the Central Vietnam, with a land not favoured by nature, frequently affected by floods, storm and drought. Most of the cultivated land belongs to the white sandy soil group (Haplic Arenosols as in FAO-UNESCO soil classification system), with a total area of about 215.3 thousand ha, distributed along the coast from Thanh Hoa to Thua Thien Hue [Loan et al. 2016]. It is a livelihood source for approximately 5 million people in the region. The coastal sandy soil is characterized by granular structures, low level of nutrients, fertility, organic matter (OM) and clay content as well as low cation exchange capacity (CEC), which negatively affects the agricultural production. Thereby, the improvement of water and nutrient retention of sandy soil is a necessary solution to promote the agricultural development in this area. The research of biochar application as well as combination of biochar and clay-rich soil for sandy soil reclamation is still limited, so this study was carried out in greenhouses with pot experiments using materials including biochar and clay-rich soil to improve the physical and chemical properties of coastal sandy soil in the Central region of Viet Nam for agricultural cultivation. The authors hypothesized that the higher application rate of biochar and clay-rich soil would result in the better water holding capacity, nutrient retention and these positive effects would increase in time.

\section{MATERIAL AND METHODS}

The experiment was conducted under greenhouse conditions of Vietnam National University of Agriculture (21 $1^{\circ} 00^{\prime} 05.4$ ' $\mathrm{N}$ and $105^{\circ} 55^{\prime} 50.8^{\prime \prime}$ E) in plastic pots system, within the period from February to June 2019 ( $1^{\text {st }}$ season$)$, from August to December 2019 ( $2^{\text {nd }}$ season) and February to June 2020 ( $3^{\text {rd }}$ season). The average annual temperature in the greenhouse area was $24.3^{\circ} \mathrm{C}$, average humidity was $85.1 \%$ (average data in 20 years 2001-2020). The tested sandy soil had characteristics of light sandy texture with $97.1 \%$ structure of fine sand, acidity with $\mathrm{pH}_{\mathrm{KCl}}$ from $4.2-4.8$, low rate of organic matter content (OM) $0.04-0.07 \%$, $0.02-0.07 \%$ total $\mathrm{N}$ and $0.02-0.04 \%$ total $\mathrm{P}$, very poor potassium $0.09-0.14 \%$, poor nutrient CEC from $0.68-0.87 \mathrm{meq} 100 \mathrm{~g}^{-1}$, and low water holding capacity (WHC) indicated through indicator of field capacity moisture (FC) from 16.8-18.1\% (w/w), bulk density $1.84 \mathrm{~g} \mathrm{~cm}^{-3}$, particle density $2.67 \mathrm{~g} \mathrm{~cm}^{-3}$. It has been dried under natural conditions, before combining with biochar and clayrich soil.

The biochar for experiment was produced from rice husks (RH), $\mathrm{RH}$ were dried for 5 days (the original rice husks were dehydrated ensuring storage condition), then smelted by springs. RH were burned under anaerobic conditions for 3-4 hours, the highest temperature was about $500-600^{\circ} \mathrm{C}$, the organic components of $\mathrm{RH}$ after burning were converted into ash containing metal oxide, silicon oxide components with high percentage. RH is black and has a porous structure with many pores. Biochar is composed of $75.6 \%$ water, volatile organic substances that can burn and decompose, $24.4 \%$ inorganic substances that do not decompose in the temperature range of $34.9-765.8^{\circ} \mathrm{C}$. The main elements in biochar include C (38.81-45.15\%), O (2.69-16.32\%), $\mathrm{N} \quad(0.22-0.69 \%), \quad \mathrm{H} \quad(0.28-2.50 \%), \quad \mathrm{O} / \mathrm{H}$ (0.05-0.27), H/C (0.08-0.67), $\mathrm{pH}_{\mathrm{H} 20}(6.84-9.62)$, BET-soi surface areas $\left(193.70-295.57 \mathrm{~m}^{2} \cdot \mathrm{g}^{-1}\right)$ [Jindo et al. 2014].

The clay-rich soil has a clay content of $25-45 \%$, balanced nutrition content, good fertility, and average humus content. This clay-rich soil is less acidic with $\mathrm{pH}$ from 5.8-6.2, the content 
of OM is at an average of $1.69-1.75 \%$, the average percentage of clay particles is from $36-53 \%$, 22.4-26.8 meq $100 \mathrm{~g}^{-1} \mathrm{CEC}$ and basic saturation is less than $50 \%$.

The experiment was conducted with a completely randomized design (CRD), each experimental formula was repeated 5 times. Five kilogrammes of all treatment mixtures and the untreated soil were placed into plastic pots $(19 \times 15 \times 20 \mathrm{~cm})$. A total of 10 treatments were performed including Control (T0), sandy soil was mixed with different rate of biochar from $0.5-1.5 \%$ (T1-T3), mixing sandy soil with $10 \%$ $(\mathrm{w} / \mathrm{w})$ clay-rich soil and biochar from $0.5-1.5 \%$ (w/w) (T4-T6) and mixing sandy soil with $15 \%$ (w/w) clay-rich soil and biochar from $0.5-1.5 \%$ (w/w) (T7-T9). L14 local peanut variety was used for experiment. The drip irrigation techniques with 30 minutes each irrigation time was applied to maintain the limit of about $70-80 \%$ of field capacity moisture. Soil moisture was maintained from $70-80 \%$ of the field capcity moisture during the growing period of peanut. It was higher during flowering period (80-85\%), decreased during the ripening period. The total irrigation water in whole one season was 6.6 liters per pot. All treatments were fertilized with phosphate fertilizer after ten days of sowing with the dose of $100 \mathrm{~g}$ per one treatment and applied nitrogen, lime to promote fruit after one month of sowing with $50 \mathrm{~g}$ per one treatment.

Soil moisture was measured by a tensiometer to determine the irrigation schedule. The soil samples were collected at the end of the each crop season and analyzed at the laboratory of Thuyloi University, Hanoi, Viet Nam to monitor the change of soil properties by treatments. Soil bulk density (BD) was determined by Blake's method [Blake 1965]. The permeability coefficient of soil was determined by routine laboratory permeability test with variable head permeability test. The soil moisture characteristic curve was determined by using a high pressure potentionmeter with a 5-bar air intake plate made by Eijkelkamp.

Soil $\mathrm{pH}_{\mathrm{KCl}}$ was determined by using the electrode method. The soil was extracted by $\mathrm{KCl}$ $1 \mathrm{~N}$ solution in the ratio of 1:5 and measured by Horiba handheld $\mathrm{pH}$ electrode meter. The cation exchange capacity (CEC) of soil was determined with the ammonium acetate method with $\mathrm{pH}=7$ [Chapman 1965], extract exchangeable cations by $\mathrm{NH}_{4} \mathrm{AC} 1 \mathrm{M}, \mathrm{pH} 7$, filting $\mathrm{NH}_{4}^{+}$by $\mathrm{KCl}$ $1 \mathrm{M}$. Total $\mathrm{N}$ was determined with the Kjeldahl sample beaking method and $\mathrm{N}-\mathrm{NH}_{3}$ was quantified by using colorimetric method, program 343 $\left(\mathrm{NH}_{3}-\mathrm{N}\right)$, wavelength $655 \mathrm{~nm}$, DR5000 equipment [Bremner 1965]. Total $\mathrm{P}$ was determined by destroying the soil in a solution of $\mathrm{H}_{2} \mathrm{SO}_{4}$ and $\mathrm{HClO}_{4}$ digested, digested soil $\mathrm{PO}_{4}{ }^{3-}$ by colorimetric method of 490 program, wavelength $375 \mathrm{~nm}$, DR5000 equipment [Olsen 1965]. The content of OM was analyzed by Walkley-Black method [Broadbent 1965].

In addition, in order to monitor effect of treatments to the individual productivity of peanut, the authors monitored pod fresh weight and pod dry weight of the peanut that were determined by content fresh samples and drying until the weight were unchanged then weighing again.

Statistical analysis. The one-way anova of variances (ANOVA) using SPSS version 22 was conducted. The $p$ values less than 0.05 were considered statistically significant and post-hoc one way anova with LSD test was used for the comparision significant difference on the effects of various treatments.

\section{RESULTS AND DISCUSSION}

Biochar amendment and biochar with clayrich soil play a role in improving the sandy soil water retention properties and enhancing nutrient retention.

Change in physical properties of sandy soil. The physical properites of sandy soil including soil bulk density, permeability coefficient and

Table 1. Detail of treatments

\begin{tabular}{|l|c|}
\hline \multicolumn{1}{|c|}{ Treatments } & Notation \\
\hline Sandy soil (Control) & T0 \\
\hline Sandy soil + biochar $0.5 \%(w / w)$ & T1 \\
\hline Sandy soil + biochar $1 \%(w / w)$ & T2 \\
\hline Sandy soil + biochar $1.5 \%(w / w)$ & T3 \\
\hline $\begin{array}{l}\text { Sandy soil + clay-rich soil } 10.0 \%+\text { biochar } \\
0.5 \%(w / w)\end{array}$ & T4 \\
\hline $\begin{array}{l}\text { Sandy soil + clay-rich soil } 10.0 \%+\text { biochar } \\
1.0 \%(w / w)\end{array}$ & T5 \\
\hline $\begin{array}{l}\text { Sandy soil + clay-rich soil } 10.0 \%+\text { biochar } \\
1.5 \%(w / w)\end{array}$ & T6 \\
\hline $\begin{array}{l}\text { Sandy soil + clay-rich soil } 15.0 \%+\text { biochar } \\
0.5 \%(w / w)\end{array}$ & T7 \\
\hline $\begin{array}{l}\text { Sandy soil + clay-rich soil } 15.0 \%+\text { biochar } \\
1.0 \%(w / w)\end{array}$ & T8 \\
\hline $\begin{array}{l}\text { Sandy soil + clay-rich soil } 15.0 \%+\text { biochar } \\
1.5 \%(w / w)\end{array}$ & T9 \\
\hline
\end{tabular}




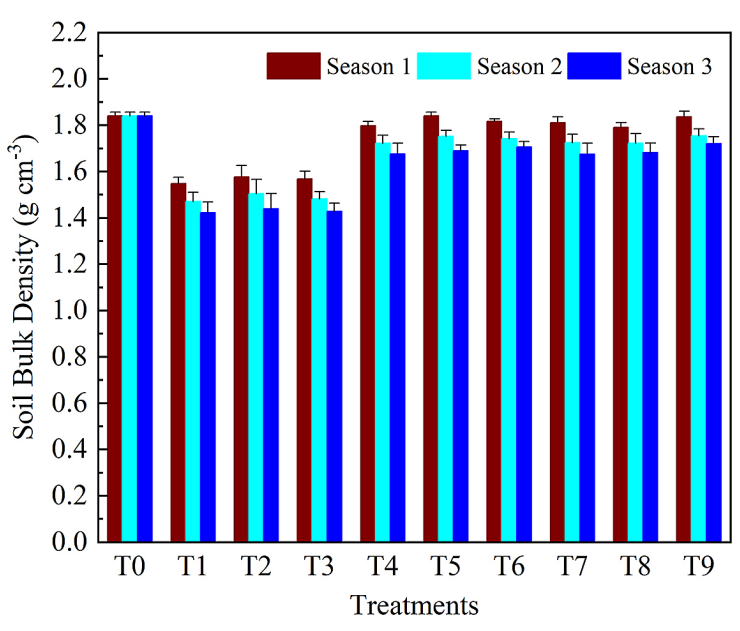

Figure 1. The change of soil bulk density by treatments in three crop seasons

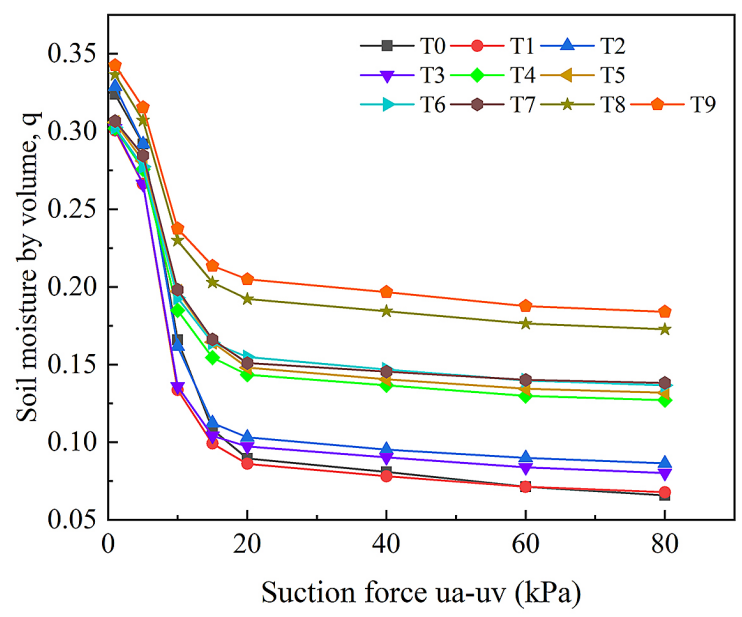

Figure 3. Soil moisture characteristic curve by treatments

soil moisture curve were assessed, the results are given in Figure 1, Figure 2 and Figure 3.

The results showed that the treatments of the tested sandy soil with biochar significantly reduced the average soil BD from $18.1-19.6 \%$ with the following order $\mathrm{T} 1(1.48)<\mathrm{T} 3(1.49)<\mathrm{T} 2$ (1.51) during three seasons. However, in the case of application of both clay-rich soil and biochar showed the BD decreased less with only from $3.8-5.9 \%$. Treatment of T1 with biochar application of $0.5 \%$ reduced BD of sandy soil most significantly (Figure 1). The results also showed that all treatments significantly reduced the average soil permeability coefficient from 53.2-96.2\%, this is great significance in proving the water holding capacity of all treatments compared to control. T9 treatment obtained the most prominent effect, since the permeability coefficient in this

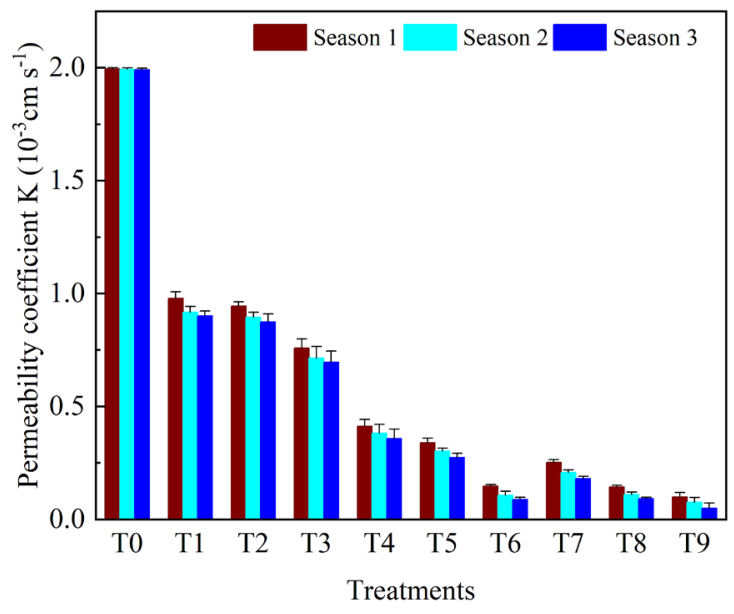

Figure 2. The change of permeability coefficient by treatments in three crop seasons

treatment reduced permeability best with more than 26.5 times compared to control (Figure 2).

The result of reduction in $\mathrm{BD}$ is consistent with recent studies in the world. Through a 3-years field experiment research, Chen et al. [2011] showed there was a noticeable improvement in the physical and chemical properties of tested soil with biochar application, of which biochar helps reduce the BD of soil in the layer 0-7.5 cm [Chen, H.X et al. 2011]. Mukherjee and Lal [2013] also indicated that using Biochar at rate from $1-2 \%(\mathrm{w} / \mathrm{w})$ significantly improved soil BD and WHC [Mukherjee and Lal 2013]. The research by Githinji [2014] showed that biochar helped BD decrease linearly from 1.325 to $0.363 \mathrm{~g} \mathrm{~cm}^{-3}\left(\mathrm{R}^{2}=0.997\right)$ with the increase of biochar application ratio $(0,25,50$ and $100 \%)$, soil porosity increased from $55-70 \%\left(\mathrm{R}^{2}=0.994\right)$, the water volume increased from 3.9 to $14 \%$.

In order to verify the water holding capacity of the treatments, the soil moisture characteristic curve was determined at the end of the third crop season. Soil moisture characteristic curve determines the relationship between the amount of water retained in soil (mass or volume water content) with suction force (ua-uw) (Figure 3). The results in Figure 3 indicate that the application of of clay-rich soils combined with biochar improved the water holding capacity of the sandy soil relatively significantly. Meanwhile, the solo application of biochar increased the water holding capacity insignificantly. The moisture by volume retained reached highest in the T9 treatment with clay-rich soil $15.0 \%$ and biochar $1.5 \%$. The higher the application rates of clay-rich soil and biochar, the better the water holding capacity of 
the sandy soil; however, the improvement rate will decrease gradually. Therefore, choosing the most effective mixing ratio may not be the highest rate in this study. For example, when applying a suction force $80 \mathrm{kPa}$, the amount of water retained in the untreated sandy soil (control) was $20 \%$ of the original amount of water, while the amount of water retained in the soil of the remaining treatments with the following order T0 $(20.3 \%)<\mathrm{T} 1(22.6 \%)<\mathrm{T} 2(26.3 \%)<\mathrm{T} 3(26.5 \%)$ $<\mathrm{T} 4(42.1 \%)<\mathrm{T} 5(43.1 \%)<\mathrm{T} 6(45.2 \%)<\mathrm{T} 7$ $(45.1 \%)<\mathrm{T} 8(51.3 \%)<\mathrm{T} 9(53.7 \%)$. The conclusion of the best mixing formulation is combined with the results of crop yield; however, the increased rate of WHC showed that the selection of the mixing ratio of clay-rich soil at the rate $10 \%$ combined with biochar is more effective in terms of economic factors and technical feasibility in the implementation process in the field.

Githinji [2014] also showed that biochar positively improvess the physical and hydraulic properties of soil when mixed together [Githinji 2014]. Biochar increases porosity and pore spaces, thus significantly increasing the water holding capacity as well as improving the sandy soil stability. Using biochar improves the soil structure including: BD, porosity, WHC, available water for crops, as well as specific surface area [Głąb et al. 2016]. Three mechanisms to increase soil porosity when adding biochar include: (i) Biochar addition helps to increase pores in the soil due to high porosity of itself; (ii) the pore system changes when cumulative pores are created and (iii) aggregate cumulative stability is ensured. According to Basso et al. [2013], the addition of biochar in sandy soil helped to increase water

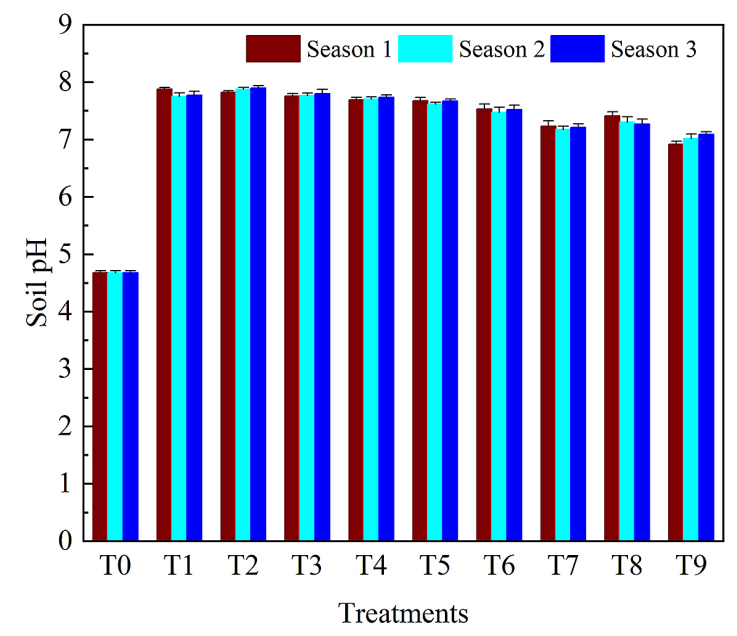

Figure 4. The change of soil $\mathrm{pH}$ by treatments in three seasons retention and available water for crops up to $23 \%$ compared to control with gravity drainage; meanwhile, BD decreased by $9 \%$ compared to control [Basso et al. 2013]. Biochar amendment increased the WHC of the tested soil by $11 \%$ [Karhu et al. 2011]. The action mechanisms of biochar help to improve WHC through the change of pore distribution, the residence time of the soil solution, and the main path of nutrient components. The research by Horák [2019] showed that the increase of application rate of biochar and biochar with $\mathrm{N}$ fertilization resulted in lower $\mathrm{BD}$, meanwhile soil moisture was increased up to 1 to $15 \%$ on average [Horák et al. 2019].

The effects of treatments to chemical indicators of the tested sandy soil including $\mathrm{pH}_{\mathrm{KC}}$, $\mathrm{CEC}$, $\mathrm{OM}$, total $\mathrm{N}$ and total $\mathrm{P}$ are given in Figures 4, $5,6,7$ and 8 below.

All treatments increased the chemical properties in terms of $\mathrm{pH}, \mathrm{CEC}, \mathrm{OM}$, total $\mathrm{N}$ and total $\mathrm{P}$ in time. The treatment of T2 with $1.0 \%$ biochar application had significant increase in average $\mathrm{pH}_{\mathrm{KCl}} 3.19$ unit (up to 7.87), the other treatments increased $\mathrm{pH}$ from 2.33 to 3.12 units from the control. Meanwhile, T9 treatment with $15.0 \%$ clay-rich soil and $1.5 \%$ biochar increased CEC to the highest extent with 16.71 units; the remaining treatments increased CEC from 2.48 to 13.47 units compared to control. Similarly, the highest values of total $\mathrm{N}$, total $\mathrm{P}$ and $\mathrm{OM}$ were also reached in this T9 treatment. The increase of clay-rich soil application rate resulted in a significant increase in $\mathrm{OM}$, total $\mathrm{P}$ and total $\mathrm{N}$ as well. A slight increase (0.17-0.56 unit) in $\mathrm{OM},(0.16-0.72$ units) in total $\mathrm{N}$ and (0.01-0.02 units) in total $\mathrm{P}$ were measured by solo biochar

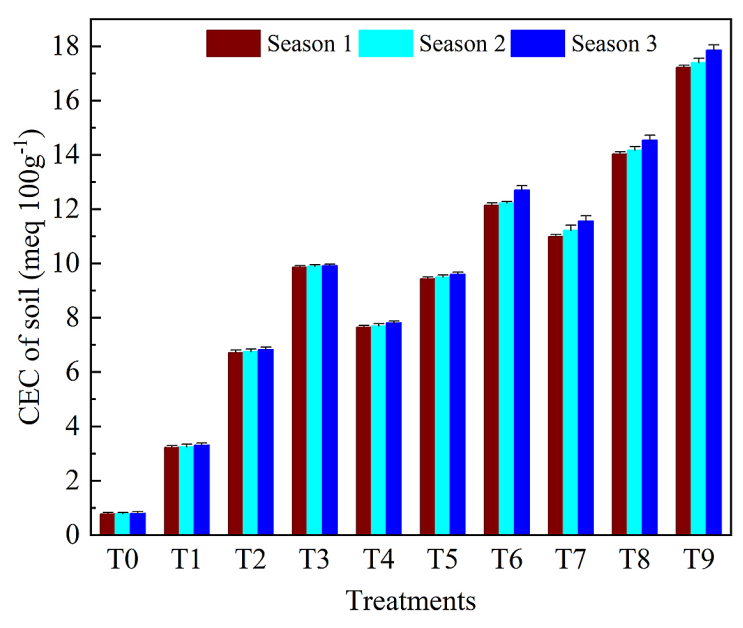

Figure 5. The change of CEC by treatments in three seasons 


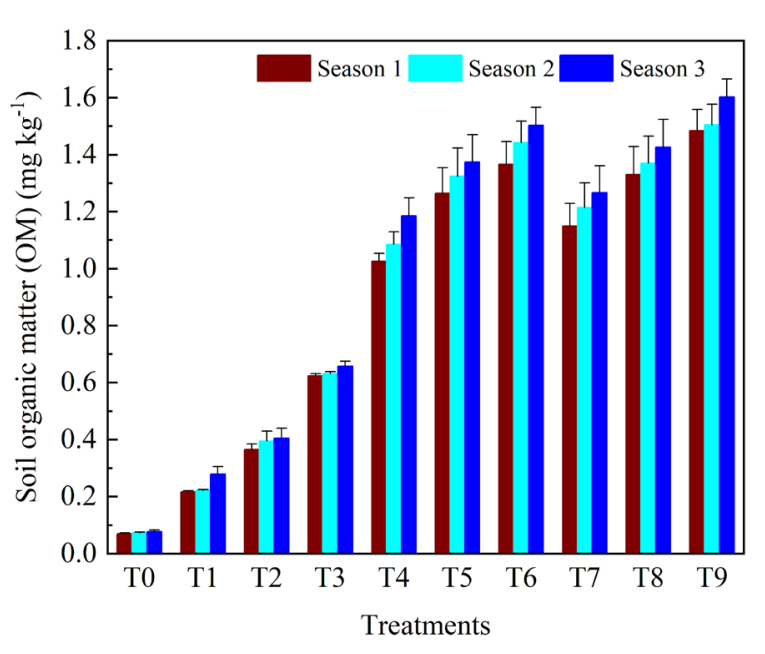

Figure 6. The change of OM by treatments in three seasons

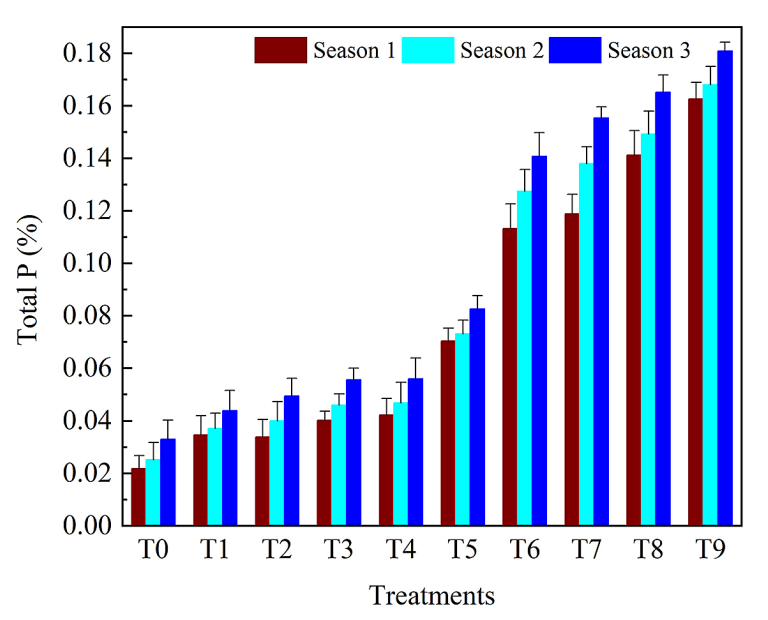

Figure 8. The change of total $\mathrm{P}$ by treatments in three seasons

application during three growing seasons. The results above can be confirmed that mixing the sandy soil with only biochar affects the organic matter content $(\mathrm{OM})$, total $\mathrm{N}$, total $\mathrm{P}$ to a limited extent while the combination of both biochar and clay-rich soil had a marked effects in increasing $\mathrm{OM}$, total $\mathrm{N}$ and total $\mathrm{P}$ for the tested sandy soil.

The biochar application helped to increase the soil pH in most published studies [Oladele 2019, Rajesh et al. 2014]. Abid et al. [2017] founded that with $1 \%$ biochar amended soil increased soil $\mathrm{OM}$ and $\mathrm{pH}$ of 1.2 and 5 times, respectively [Abid et al. 2017]. The mechanism of increasing the $\mathrm{pH}$ of the soil has been explained by the release of alkaline substances present in biochar [Yuan and $\mathrm{Xu}$ 2011, Luo et al. 2017]. Yuan and Xu [2011] found a positive relationship between soil $\mathrm{pH}$ and alkalinity of biochar. At the same time, the

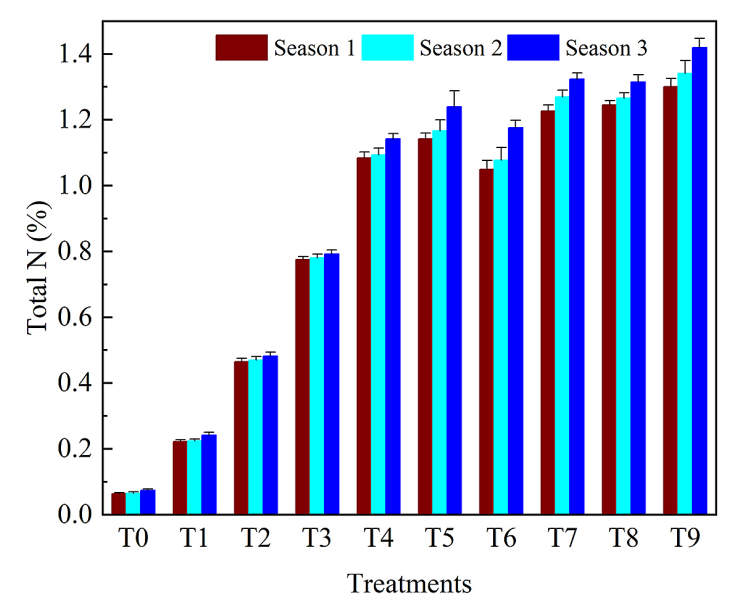

Figure 7. The change of total $\mathrm{N}$ by treatments in three seasons

functional groups containing oxygen in biochar negatively charged phenolicm carboxyl and hydroxyl on the surface of biochar bind with $\mathrm{H}+$ ions from the soil solution, thereby reducing the concentration of $\mathrm{H}^{+}$ions, contributing to an increase in the soil $\mathrm{pH}$ value [Chintala et al. 2014]. Moreover, silicate, carbonate and bi-carbonate derived from biochar can bind with $\mathrm{H}^{+}$ion and thereby remove them from the soil solution. Biochar will provide protons through reactions at high $\mathrm{pH}$ and bonding reactions at low $\mathrm{pH}$ thus changing the $\mathrm{pH}$ in soil, which is also explained as a mechanism to increase the soil $\mathrm{pH}$ [BlancoCanqui 2017, Liu et al. 2017]. When the $\mathrm{pH}$ in sandy soil increases, it will help change the form of available nutrients and facilitate the absorption of ions for the roots. A 3-year study conducted by Oladele [2019] showed that biochar has the effects of increasing $\mathrm{pH}, \mathrm{CEC}$ as well as reducing soil $\mathrm{BD}$, and increasing WHC. At the same time, the research also showed that biochar has a long-term effect on the physical properties of soil rather than improving the chemical parameters. The effect of biochar on some indicators such as: conductivity, organic carbon, total $\mathrm{N}$ and $\mathrm{C}: \mathrm{N}$ ratio decreases after 3 years while $\mathrm{pH}$, CEC, WHC are improved consistently [Oladele 2019]. The research by Rens et al. [2018] showed that mixing biochar improves soil characteristics, soil quality and nutrient retention, and enhances carbon sequestration. They investigated the adsorption of $\mathrm{NH}_{4}-\mathrm{N}, \mathrm{P}$ and $\mathrm{K}$ in sandy soil with different admendment of biochar at rates of 0 ; 22.4 and $44.8 \mathrm{mg} \mathrm{ha}^{-1}$. The nutrients retained by biochar are easily released and are easily for the 
taken up by plant roots that hold water in the soil and enhance the ability to retain nutrients [Rens et al. 2018]. Ghorbani et al. [2019] studied the effect of biochar on the physical-chemical properties and the loss of nitrate in sandy soil and clay pointed out with $1 \%$ and $3 \%$ of biochar application rates increased $9 \%$ and $19 \%$ CEC in clay soil and increased up to $20 \%$ and $30 \%$ CEC in loamy sandy soil [Ghorbani et al. 2019]. The increase in CEC in sandy soil is explained by the increase in surface charge due to biochar and clay-rich soils, which increases CEC and soil nutrients [Nelissen et al. 2012, Atkinson et al. 2010]. The nutrient retention ability of soil mixed with biochar due to the large specific surface area, and the functional carboxylic groups on the surface of biochar to create complexes with the ions thus preventing nutrient loss [Cheng et al. 2006]. A long-term research of Reuter [1994] showed the treatment of 19 tons $\cdot \mathrm{ha}^{-1}$ of clay increased the organic content by 2 units, CEC increased by 9 units in 6th year and $\mathrm{OM}$ increased by +7 units, CEC increased by 20 units in 15th year [Reuter 1994].

Nitrogen is a key element of crop growth and is easily lost due to reduction and evaporation. The addition of biochar decreased soil $\mathrm{N}$ losses thereby improving nutrient use efficiency [Li et al. 2019, Shaaban et al. 2018]. The mechanism of soil nutrient retention in biochar and clay-rich soil was also explained by the zeta surface potential of colloidal particles. Yao et al. [2012] discovered the good retention of $\mathrm{NO}_{3}$ - in soils using different types of biochar materials produced at different pyrolysis temperatures [Yao et al. 2012]. Kameyama et al. [2012] also observed $\mathrm{NO}_{3}^{-}$adsorption on the biochars produced from sugarcane bagasse residues from pyrolysis at five different temperatures and the degree of adsorption was dependent on temperature, the degree of adsorption increases with the increase of the pyrolysis temperature [Kameyama et al. 2012]. Liu et al. [2017] and Wang et al. [2017] found that biochar addition helped to reduce nitrogen filtration by holding nitrates, thereby increasing crop efficiency. A number of mechanisms have been suggested in explaining the reduction of filtration and storage of $\mathrm{N}$ in the soil applying biochar. Those included: adsorption, immobilization, and ion exchange of $\mathrm{NO}_{3}^{-}$và $\mathrm{NH}_{4}^{+}$on biochar [Liu et al. 2017, Wang et al. 2017]. Mechanical disturbance when applying biochar increases soil aeration and promotes nitrification causing a rapid transition from $\mathrm{NH}_{4}^{+}$to $\mathrm{NO}_{3}^{-}$[Abujabhah et al. 2016, He et al. 2016]. Laird et al. [2010] founded that there was a significant impact on total $\mathrm{N}$ (up to 7\%); organic carbon (up to 69\%) and P, K, Mg and Ca with biochar treatment. In addition, the biochar addition also significantly improved the quality and fertility of agricultural land in Midwest, USA [Laird et al. 2010].

Phosphorus is an essential macro-nutrient for plant growth and has been significantly added when applying biochar to soil. A study by Parvage et al. [2013] showed that the mixed ratio of wheat residue biochar at $1.0 \%$ resulted in the highest concentration of water-soluble phosphorus. Water soluble $\mathrm{P}$ concentrations increased from $11.0-25.3 \%$ in eleven soil samples applied the same biochar rate of $1 \%(\mathrm{w} / \mathrm{w})$. Increasing the application rate of biochar can lead to different effects on soil-soluble phosphorus concentrations due to the reactions that occur with $\mathrm{Ca}$ and $\mathrm{Mg}$ when adding biochar [Parvage et al. 2013]. The long-term effects of biochar on P soil were observed, leading to higher pasture yields [Slavich et al. 2013]. Increasing the available $P$ for crop after using biochar has been observed in some studies even under soil with low available P [Mukherjee et al. 2019, Glaser \& Lehr 2019].

In order to verify the soil improvement efficiency of clay-rich soil and biochar, in addition to the above-mentioned improved physical-chemical properties, the grow and yield indicators of plants have also been monitored and evaluated throughout three seasons. They include: germination rate, characteristics of flowering and number of effective flowers, the ability to form nodules, biomass accumulation during the flowing period to harvest time and individual productivity, of which the individual productitivy is the most important indicator.

Individual yield is a combination of many indicators: the number of grain per plant, pod fresh weight, pod dry weight, the ratio of 1 grain per plant, 2 grains and/or 3 grain per plant, etc. of which two main indicators, i.e. pod fresh weight and pod dry weight, are most important, which reflects productivity efficiency (Fig. 9 and Fig. 10).

All treatments increased average pod fresh weight from 102.7-319.1\% (except T3 treatment) and increased pod dry weight from $26.7-564.8 \%$, compared to control during three seasons. T9 treatment with clay-rich soil $10 \%(\mathrm{w} / \mathrm{w})$ and biochar $0.5 \%(\mathrm{w} / \mathrm{w})$ obtained the highest productivity and the post-hoc test was conducted to verify effects of treatments compared to control and all 


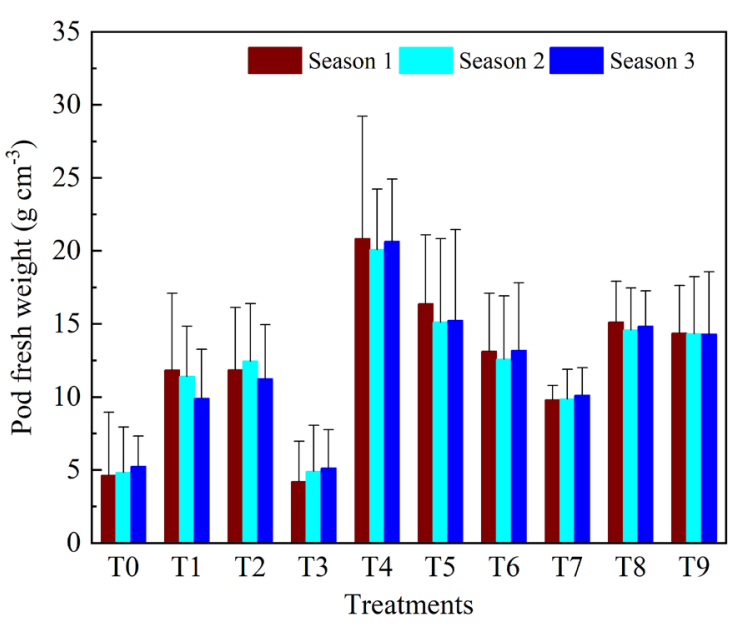

Figure 9. The change of pod fresh weight by treatments in three seasons

treatments except $\mathrm{T} 3$ treatment are statistical significance with control $(\mathrm{Sig}<0.05)$.

Recent studies revealed that biochar application can significantly increase crop growth and yield [Abid et al. 2017, Pandey et al. 2016]. Certain types of biochar can significantly improve the productivity of certain soils, while the same type of biochar added in other soil may not achieve any effect, and - in fact - it may even can cause a significant decrerase in production. According to Schulz and Glaser [2013] the addition of both biochar and compost increased the biomass yield, the height of oat and seed weight [Schulz and Glaser 2013]. The research by Yunilasari et al. [2020] also showed that the use of biochar with cow manure for sandy soil resulted in an increase in peanut weight and potential yield of peanut up to 3.96 ton $\cdot \mathrm{ha}^{-1}$ [Yunilasari et al. 2020]. The research of Reuter [1994] showed the yield increase of $9.6 \%$ to $15.4 \%$ compared to the control when using proportion of clay from 4 to 1245 tons $\cdot$ ha $^{-1}$ in his treatment [Reuter 1994].

\section{CONCLUSIONS}

The results of this study demonstrates that the combination of biochar and clay-rich soil is an effective solution for sandy soil reclamation that can increase $\mathrm{CEC}, \mathrm{OM}, \mathrm{pH}$, total $\mathrm{N}$ and total $\mathrm{P}$ as well as improve the water retention capacity of sandy soil via decrease in bulk density and permeability coefficient. The application rate of $10 \%(\mathrm{w} / \mathrm{w})$ clay-rich soil and $0.5 \%(\mathrm{w} / \mathrm{w})$ biochar is the most favourable treatment in terms of improving the chemical-physical characteristics and

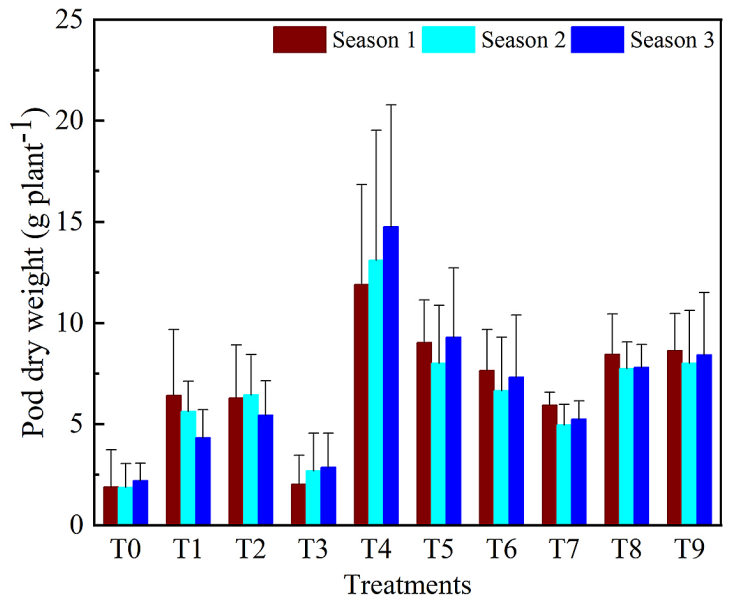

Figure 10. The change of pod dry weight by treatments in three seasons

productivity of plants. These results can be recommended for scale up at the field application.

\section{Acknowledgements}

This study was supported from the project code: ĐTĐL.CN-24/19 "Research on scientific and technological solutions for irrigation, agroforestry to improve coastal sandy soil for sustainable agricultural production in the North Central region, Viet Nam (Ha Tinh, Quang Binh, Quang Tri)" funded by Vietnamese Government through Ministry of Sicence and Technology, Vietnam.

\section{REFERENCES}

1. Abid M., Danish S., Zafar-Ul-Hye M., Shaaban M., lqbal M.M., Rehim A., Qayyum M.F., Naqqash M.N. 2017. Biochar increased photosynthetic and accessory pigments in tomato (Solanum lycopersicum L.) plants by reducing cadmium concentration under various irrigation waters. Environmental Science and Pollution Research, 24, 22111-22118.

2. Abujabhah I.S., Bound S.A., Doyle R., Bowman J.P. 2016. Effects of biochar and compost amendments on soil physico-chemical properties and the total community within a temperate agricultural soil. Applied Soil Ecology, 98, 243-253. https:// doi.org/10.1016/j.apsoil.2015.10.021.

3. Atkinson C.J., Fitzgerald J.D., Hipps N.A. 2010. Potential mechanisms for achieving agricultural benefits from biochar application to temperate soils: a review. Plant and Soil, 337, 1-18.

4. Basso A.S., Miguez F.E., Laird D.A., Horton R., Westgate M. 2013. Assessing potential of biochar for increasing water-holding capacity of sandy 
soils. GCB Bioenergy, 5(2), 132-143. https://doi. org/10.1111/gcbb.12026.

5. Blake G.R. 1965. Particle Density and Bulk Density. In: C.A. Black (Ed.), Method of Soil analysis-Part 1-Physical and Mineralogical properties, including Statistics of Measurement and Sampling. American Society of Agronomy, No. 9i, 371-390.

6. Blanco-Canqui H. 2017. Biochar and Soil Physical Properties. Soil Science Society of America Journal, 81(4), 687-711. https://doi.org/10.2136/ sssaj2017.01.0017.

7. Bremner J.M. 1965. Total Nitrogen. In: A.G. Norman (Ed.), Methods of soil analysis, Part 2-Chemical and Microbiological properties. American Society of Agronomy, pp. 1149-1178.

8. Broadbent F.E. 1965. Organic Matter. In: A.G. Norman (Ed.), Methods of soil analysis, Part 2-Chemical and Microbiological properties. American Society of Agronomy, pp. 1397-1400.

9. Chapman H. 1965. Cation-Exchange Capacity. American Society of Agronomy, pp. 891-900.

10. Chen H.X., Du Z.L., Guo W., Zhang Q.Z. 2011. Effects of biochar amendment on cropland soil bulk density, cation exchange capacity, and particulate organic matter content in the North China Plain. Ying Yong Sheng Tai Xue Bao, 22(11), 2930-34.

11. Cheng C.H., Lehmann J., Thies J.E., Burton S.D., Engelhard M.H. 2006. Oxidation of Black Carbon by Biotic and Abiotic Processes. Organic Geochemistry, 37(11), 1477-1488.

12. Chintala R., Mollinedo J., Schumacher T.E., Malo D.D., Julson J.L. 2014. Effect of biochar on chemical properties of acidic soil. Journal Archives of Agronomy and Soil Science, 60(3), 393-404. https://doi.org/10.1080/03650340.2013.789870.

13. Chintala R., Schumacher T.E., Kumar S., Malo D. D., Rice J.A., Bleakley B., Chilom G., Clay D.E., Julson J.L., Papiernik S.K., Gu Z.R. 2014. Molecular characterization of biochars and their influence on microbiological properties of soil. Journal of Hazardous Materials, 279, 244-256. https://doi. org/10.1016/j.jhazmat.2014.06.074.

14. Ghorbani M., Asadi H., Abrishamkesh S. 2019. Effects of rice husk biochar on selected soil properties and nitrate leaching in loamy sand and clay soil. International Soil and Water Conservation Research, 7(3), 258-265. https://doi.org/10.1016/j. iswcr.2019.05.005

15. Githinji L. 2014. Effect of biochar application rate on soil physical and hydraulic properties of a sandy loam. Archives of Agronomy and Soil Science, 60(4), 457-470.

16. Głąb T., Palmowska J., Zaleski T., Gondek K. 2016. Effect of biochar application on soil hydrological properties and physical quality of sandy soil. Geoderma, 281, 11-20. https://doi.org/10.1016/j. geoderma.2016.06.028.
17. Glaser B., Lehr V.I. 2019. Biochar effects on phosphorus availability in agricultural soils: A metaanalysis. Scientific Reports, 9(1), 1-9. https://doi. org/10.1038/s41598-019-45693-z.

18. Horák J., Šimanský V., Igaz D. 2019. Biochar and biochar with $\mathrm{N}$ fertilizer impact on soil physical properties in a silty loam Haplic Luvisol. Journal of Ecological Engineering, 20(7), 31-38. https://doi. org/10.12911/22998993/109857.

19. Ismail S.M., Ozawa K. 2007. Improvement of crop yield, soil moisture distribution and water use efficiency in sandy soils by clay application. Applied Clay Science, 37(1-2), 81-89. https://doi. org/10.1016/j.clay.2006.12.005.

20. Jeffery S., Verheijen F.G.A., Van der Velde M., Bastos A.C. 2011. A quantitative review of the effects of biochar application to soils on crop productivity using meta-analysis. Agriculture, Ecosystems and Environment, 144(1), 175-187. https://doi. org/10.1016/j.agee.2011.08.015.

21. Jindo K., Mizumoto H., Sawada Y., SanchezMonedero M.A., Sonoki T. 2014. Physical and chemical characterization of biochars derived from different agricultural residues. Biogeosciences, 11(23), 6613-6621. https://doi.org/10.5194/ bg-11-6613-2014.

22. Kameyama K., Miyamoto T., Shiono T., Shinogi Y. 2012. Influence of Sugarcane Bagasse-derived Biochar Application on Nitrate Leaching in Calcaric Dark Red Soil. Journal of Environmental Quality, 41(4), 1131-1137. https://doi.org/10.2134/ jeq2010.0453.

23. Karhu K., Mattila T., Bergström I., Regina K. 2011. Biochar addition to agricultural soil increased $\mathrm{CH}$ 4 uptake and water holding capacity-Results from a short-term pilot field study. Ecosystems and Environment, 140, 309-313. https://doi.org/10.1016/j. agee.2010.12.005.

24. Laird D.A., Fleming P., Davis D.D., Horton R., Wang B., Karlen D.L. 2010. Impact of biochar amendments on the quality of a typical Midwestern agricultural soil. Geoderma, 158(3-4), 443-449. https://doi.org/10.1016/j.geoderma.2010.05.013.

25. Li Q., Li H., Fu Q., Li T., Liu D., Hou R., Cuia S., Ji Y., Cai Y. 2019. Effects of different biochar application methods on soybean growth indicator variability in a seasonally frozen soil area. https:// doi.org/10.1016/j.catena.2019.104307.

26. He L., Liu Y., Zhao J., Bi Y., Zhao X., Wang S., Xing G. 2016. Comparison of straw-biochar-mediated changes in nitrification and ammonia oxidizers in agricultural oxisols and cambosols. Biology and Fertility of Soils, 52, 137-149.

27. Liu S., Meng J., Jiang L., Yang X., Lan Y., Cheng X., Chen W. 2017. Rice husk biochar impacts soil phosphorous availability, phosphatase activities and bacterial community characteristics in three different soil types. Applied Soil Ecology, 116(March), 12-22. 
https://doi.org/10.1016/j.apsoil.2017.03.020.

28. Liu Z., He T., Cao T., Yang T., Meng J., Chen W. 2017. Effects of biochar application on nitrogen leaching, ammonia volatilization and nitrogen use efficiency in two distinct soils. Journal of Soil Science and Plant Nutrition, 17(2), 515-528. https:// doi.org/10.4067/S0718-95162017005000037.

29. Loan B.T.P., Ha P.Q., T.T. 2016. Study on the current status and crop structures on sandy soil in the North Central region. Journal of Agriculture and Rural Development, 1, 01-09 (in Vietnamese).

30. Luo X., Liu G., Xia Y., Chen L., Jiang Z., Zheng H., Wang Z. 2017. Use of biochar-compost to improve properties and productivity of the degraded coastal soil in the Yellow River Delta, China. Journal of Soils and Sediments, 17(3), 780-789. https://doi. org/10.1007/s11368-016-1361-1.

31. Molnár M., Vaszita E., Farkas É., Ujaczki É., FeketeKertész I., Tolner M., Klebercz O., Kirchkeszner C., Gruiz K., Uzinger N., Feigl V. 2016. Acidic sandy soil improvement with biochar - A microcosm study. Science of the Total Environment, 563-564, 855-865. https://doi.org/10.1016/j. scitotenv.2016.01.091.

32. Mukherjee A., Lal R. 2013. Biochar Impacts on Soil Physical Properties and Greenhouse Gas Emissions. Agronomy, 3(2), 313-339. https://doi.org/10.3390/ agronomy3020313.

33. Mukherjee S., Mavi M.S., Sing J., Sing B.P. 2019. Rice-residue biochar influences phosphorus availability in soil with contrasting P status. Archives of Agronomy and Soil Science, 778-791. https://doi. org/10.1080/03650340.2019.1639153.

34. Nelissen V., Rütting T., Huygens D., Staelens J., Ruysschaert G., Boeckx P. 2012. Maize biochars accelerate short-term soil nitrogen dynamics in a loamy sand soil. Soil Biology and Biochemistry, 55, 2027. https://doi.org/10.1016/j.soilbio.2012.05.019.

35. Oladele S.O. 2019. Changes in physicochemical properties and quality index of an Alfisol after three years of rice husk biochar amendment in rainfed rice - maize cropping sequence. Geoderma, 353(June), 359-371. https://doi.org/10.1016/j. geoderma.2019.06.038.

36. Olsen S.R., Dean L.A. 1965. Phosphorus. In: A.G. Norman (Ed.), Methods of soil analysis, Part 2. Chemical and Microbiological Properties. American Society of Agronomy, pp. 1035-1049.

37. Pal S., Marschner P. 2016. Soil respiration, microbial biomass $\mathrm{C}$ and $\mathrm{N}$ availability in a sandy soil amended with clay and residue mixtures. Pedosphere, 26(5), 643-651. https://doi.org/10.1016/ S1002-0160(15)60073-X.

38. Pandey V., Patel A., Patra D.D. 2016. Biochar ameliorates crop productivity, soil fertility, essential oil yield and aroma profiling in basil (Ocimum basilicum L.). Ecological Engineering, 90, 361-366. https://doi.org/10.1016/j.ecoleng.2016.01.020.
39. Parvage M.M., Ulén B., Eriksson J., Strock J., Kirchmann H. 2013. Phosphorus availability in soils amended with wheat residue char. Biology and Fertility of Soils, 49(2), 245-250. https://doi. org/10.1007/s00374-012-0746-6.

40. Rens H., Bera T., Alva A. 2018. Effects of biochar and biosolid on adsorption of nitrogen, phosphorus, and potassium in two soils. Water, Air, \& Soil Pollution.

41. Reuter G. 1994. Improvement of sandy soils by clay-substrate application. Applied Clay Science, 9(2), 107-120. https://doi.org/10.1016/0169-1317 (94)90030-2.

42. Schulz H., Dunst G., Glaser B. 2013. Positive effects of composted biochar on plant growth and soil fertility. Agronomy for Sustainable Development, 33(4), 817-827. https://doi.org/10.1007/ s13593-013-0150-0.

43. Shaaban M., Van Zwieten L., Bashir S., Younas A., Núñez-Delgado A., Chhajro M.A., Kubar K.A., Ali U., Rana M.S., Mehmood M.A., Hu R. 2018. A concise review of biochar application to agricultural soils to improve soil conditions and fight pollution. Journal of Environmental Management, 228(April), 429440. https://doi.org/10.1016/j.jenvman.2018.09.006.

44. Slavich P.G., Sinclair K., Morris S.G., Kimber S.W.L., Downie A., Zwieten L.V. 2013. Contrasting effects of manure and green waste biochars on the properties of an acidic ferralsol and productivity of a subtropical pasture. Plant and Soil, 366, 213-227.

45. Wang Y., Liu Y., Liu R., Zhang A., Yang S., Liu H., Zhou Y., Yang Z. 2017. Biochar amendment reduces paddy soil nitrogen leaching but increases net global warming potential in Ningxia irrigation, China. Scientific Reports, 7(1), 1-10. https://doi.org/10.1038/ s41598-017-01173-w.

46. Yao Y., Zhang M., Inyang M., Zimmerman AR. 2012. Effect of biochar amendment on sorption and leaching of nitrate, ammonium, and phosphate in a sandy soil. Chemosphere, 89(11), 1467-1471. https://doi. org/10.1016/j.chemosphere.2012.06.002.

47. Yuan J., Xu R. 2011. The amelioration effects of low temperature biochar generated from nine crop residues on an acidic Ultisol. Soil Use and Management, 27(1), 110-115. https://doi. org/10.1111/j.1475-2743.2010.00317.x.

48. Yunilasari M., Sufardi., Zaitun. 2020. Effects of biochar and cow manure on soil chemical properties and peanut (Arachis hypogaea L.) yields in entisol. IOP Conference Series: Earth and Environmental Science, 425, 012014. https://doi.org/10.1088/1 755-1315/425/1/012014.

49. Zeid H.A., Wafaa H.M., I.I. Abou El Seoud., Alhadad, W.A.A. 2015. Effect of organic materials and inorganic fertilizers on the growth, mineral composition and soil fertility of radish plants (Raphine's sativus) grown in sandy soil. Middle East Journal of Agriculture Research, 4(01), 77-87. 